\title{
LIVRO DE ARTISTA: PROCESSO DE CRIAÇÃO EM PERFORMANCE E POÉTICAS VISUAIS EM UMA ESCOLA AMAPAENSE
}

\author{
Maria Pinho Gemaque \\ GEA/AP
}

\section{Resumo}

A lógica da pesquisa desenvolvida intercambia vivências dentro do espaço escolar nas aulas de arte com processos de criação, intervenção artística/educativa desenvolvidas na Escola Estadual Raimunda Virgolino, Macapá/AP/Brasil. Trata-se de um trabalho coletivo que envolveu estudantes do Ensino Médio, professoras de Arte e artistas amapaenses. Procurou compreender os enlaces dos processos de criação em arte por meio de ações em performances de alunos e professores. $O$ estudo possui caráter qualitativo por entender as relações entre os indivíduos, e, por isso, de intenção etnográfica, inspirado pela metodologia $a / r /$ tográfica. Esse processo metodológico engendra saberes entre a atividade do professor/artista que investiga e constrói significados sobre a sua prática a partir de experiências artísticas e educativas. Foi produzido um material que se atem a desvelar o processo de criação imerso na pesquisa: um livro de artista contendo quatro conversas interativas, um CD do filme "Viagens Poéticas" e imagens dos processos que se desaguam em mesas de cafés, encontro com teóricos e com as cidades que estão atravessadas nestas conversas pesquisantes. Os fins - e - afins inacabados da investigação consiste em aproximação e diálogos horizontalizados entre alunos e professor, diluir fronteiras entre saberes e fazeres do conhecimento em educação em arte, apropriações percepções artísticas e estéticas em torno da vida dentro do ambiente escolar.
Abstract

The logic of the research that was developed exchanges with the experiences within the space of coexistence in the art classes with processes of creation, artistic / educational intervention developed in the State School Raimunda Virgolino, Macapá / AP / Brazil. It is a collective work that involved high school students, art teachers and amapaenses artists. It sought to understand the links of the processes of creation in art through actions in performances of students and teachers. The study has a qualitative character because it understands the relations between individuals, and therefore of ethnographic intention, inspired by the a/r/tographic methodology. This methodological process generates knowledge between the activity of the teacher / artist who investigates and constructs meanings about his practice based on artistic and educational experiences. A material was produced which began to reveal the process of creation immersed in research: an artist's book containing four interactive talks, a CD of the movie "Poetic Travels" and images of the processes that pour into coffee tables, meeting with theorists and with the cities that are going through these research conversations. The unfinished ends and ends of the research consist of horizontal approximation and dialogues between the students and their teacher, diluting boundaries between knowledge and actions knowledge in art education, appropriation of artistic and aesthetic perceptions around life within of the school environment.

Keywords:

Art Teaching; Art Education; Performance;

A/r/tography; Book of Artist.

Ensino de Arte; Performance;

A/r/tografia; Livro de Artista. 


\section{CONSIDERAÇÕES INICIAIS: PESQUISA ENTRE CIDADES.}

Este trabalho foi construído de forma coletiva com diálogos, com encontros entre professores, alunos, amigos, viagens e mesas de café. Durante a minha vivência pesquisante no Programa de Mestrado Profissional em Artes (Prof-Artes), na Universidade Federal do Pará (UFPA). Com suporte nos temas Livro de artista e criações poéticas com estudantes, em que a arte descobriu caminhos para problematizar e compreender os deslocamentos/atravessamentos ${ }^{1}$ artísticos-estéticos e perceptivos no espaço da escola e da casa dos estudantes, e considerou-os como lugares de experimento e vivência artística para fazer, refletir e expressar sensações, emoções, fatos sociais/sociológicos, culturais, psicológicos, geográficos e cotidianos, através das poéticas visuais: performances instalativas, intervenções e desenhos. Ocupando o ambiente escolar com arte, e diluindo fronteiras, ora entre a escola e a casa dos estudantes, ora entre aluno e professor dentro da escola.

Nesta conversa/ocupação os estudantes externaram/imprimiram as questões/fatos que os inquietavam e os incomodavam na escola e na vida, por meio das poéticas artísticas que produziram, pois o meu interesse pelo tema em questão atravessa-me desde a graduação em arte. Sempre levantei questionamentos sobre o ser artistaprofessora e sobre o pensar-fazer e refletir arte, por meio dos processos de criação em performance e poéticas visuais nas aulas de arte, "por conta disso fiz escolhas investigativas que me levaram a caminhos de pesquisa qualitativos por meio dos quais buscou uma postura compreensiva de acesso a produção artística" (MARQUES, 2017, p. 17), realizadas no ambiente escolar por professoresartistas, estudantes e outros artistas convidados.

Ao realizar uma pesquisa, mergulhamos de corpo e alma em um processo longo e que, ao concluir todos os aprendizados, aparecem entranhados em nossa pele. Esse processo/estado de entranhamento conduz à licença poética que me permite a fala/ performance do processo vivido. Esse texto, ora literário, ora poético, ora investigativo, se mescla em sensações de processos pesquisantes, e tornase um registro deste entranhamento:

Foi neste processo de idas e vindas que a pesquisa se desenvolveu numa proposição $A / r /$ tográfica, que experimentou e vivenciou processos de produção em artes, por meio da performance. Buscou compreender deslocamentos perceptivos, compreensões, espaços de vivência no fazer do ensino de arte e atravessamentos.

A escrita é de uma percepção singularizada, tanto linguística quanto perceptivamente, por viver e experimentar as particularidades e a vida cabocla das ribeiras amazônica², como artistaperformer-professora e pesquisadora que vivencia a sua prática artística na escola e nos entre meios do ensino de arte, através dos encontros com a Pesquisa Baseada em Arte (PBA) e a Pesquisa Educacional Baseada em Arte (PEBA) que: "buscam deslocar internacionalmente modos de se fazer pesquisa e conhecimentos em artes, ao aceitar e ressaltar categorias como incerteza, imaginação, ilusão, introspecção, visualização e dinamismo" (DIAS, 2013, p. 23).

Estes modos sublinhados pelo autor, estão presentes nas travessias pesquisantes que costumo fazer "como artista e professora" (RANGEL, 2006, p. 01), no espaço do ensino de arte, ao receber convites de arte/educadores, tal como aconteceu com a professora Rosilene Lobato $^{3}$ ao deslocar-me da galeria ${ }^{4}$ da Universidade Federal do Amapá (UNIFAP), enquanto performer para as suas aulas de arte e, assim, construir conversas poéticas entre teoria e prática, onde produzimos performance, instalação, intervenção e desenhos com os estudantes do segundo e terceiro ano do Ensino Médio, e com outros artistas/professores/ pesquisadores que atuam na cidade.

E como produto dessa vivência, nasceu um livro de artista, que "carrega" em suas folhas quatro conversas interativas que direcionaram os caminhos e as viagens de criação em arte, durante os experimentos realizados nas aulas de arte; um filme documentário de performance e outros registros imagéticos das ações desenvolvidas. Desse modo, estou implicada/imersa neste trabalho, assim como ele tem potencial de agente nas minhas ações pessoais e profissionais, também criou caminhosconversas e vivência pesquisante com os intensões de uma pesquisa etnográfica envolvida diretamente com a vida, com os lugares e com as questões sociais e culturais que estão entranhadas na vida dos estudantes, de forma ritualística, que propõem encontros com "antropologia da performance" como sugere Schechner (2006). 
E a partir deste processo o problema levantado durante as conversas pesquisantes se fez presente no momento em que os estudantes ocuparam a escola com performance e poéticas visuais, pois mudaram a rotina diária do ambiente escolar e, até mesmo, os professores das outras áreas do conhecimento cederam suas aulas/horários e se envolveram no processo de criações artísticas, alguns participaram das ações, inclusive tomando como instrumento avaliativo. Neste momento o ensino de arte conduziu a ocupação no ambiente e a poética se fez presente. Ao deparar-me com essas ações artísticas, sentir a necessidade de olhar para os processos de criações poéticas realizados na escola, através da etnografia, conforme o destaque dado por Marques (2017) quando afirma que:

\begin{abstract}
Mesmo eu não tendo sido educada nesta vertente da antropologia, que tem o cuidado com a observação das práticas sociais, e sim na área de artes visuais, onde a visão e a visualidade são formas de interpretar e perceber as ações artísticas como práticas sociais, considero a aproximação das duas áreas de conhecimento com diálogos profícuos que contribuem para ampliar e aprofundar as percepções e interpretações sobre este mundo que se tornou cada vez mais visual (MARQUES, 2017, p. 19).
\end{abstract}

Esta fala deslocou-me como artista-professora, atuante no Centro Cultural Franco Amapaense (CCFA), na Educação Profissional do Ensino Médio em cursos de formação inicial e continuada, a ter um olhar mais atento, curioso e preocupado com as ações sociais que envolvem os estudantes do segundo e terceiro anos do Ensino Médio, como os que fizeram parte desta conversa pesquisante. Busquei caminhos interativos e metodológicos para fazer-trocar e criar espaços de vivência entre prática e teoria no ensino de arte, proporcionando interatividade com a comunidade escolar. Percebi que os estudantes criaram formas de viver dentro da escola, de pertencer ao lugar, através da ocupação e dos trabalhos que foram desenvolvidos no ambiente escolar, os quais transformaram o ambiente e trouxeram muitas reflexões artísticas.

Metodologicamente, estou atravessada por uma pesquisa de caráter qualitativo, com olhares etnográficos que dialogam com a antropologia da performance e com "a/r/tografia (artistresearcher-teacher), circunscrita no fazer da Pesquisa Educacional Baseada em Arte (PEBA), que problematiza sobre os saberes inerentes nas relações transfronteiriças da ação do artista, pesquisador e professor" (DIAS, 2013, p. 23). Esta metodologia caracteriza-se por ser um circuito vivo e em constante processo de construção que envolve compreensões, experiências e representações. Ou seja, quando os "problemas de pesquisa estão imersos nas práticas de artistas, educadores ou artistas-educadores e, portanto, têm o potencial de influenciar essas práticas" (IRWIN, 2013, p. 29). Influenciadas/envolvidas pela $a / r /$ tografia, temos a licença poética para questionar, pesquisar e viver o nosso fazer artístico e a "educação da visualidade" (DIAS e FERNÁNDEZ, 2014, p. 110) na comunidade escolar. Pois,

$a / r /$ tografia é uma forma de representação que privilegia tanto o texto (escrito) quanto a imagem (visual) quando eles se encontram em momento de mestiçagem ou hibridização. A/R/T é uma metáfora para Artist (artista), Research (pesquisador), Teacher (professor) e graph (grafia: escrita ou representação). Na a/r/tográfia saber, fazer, e realizar se fundem [...]" (DIAS, 2013, p. 25).

E nesta fusão metodológica, re(de)senhei as minhas buscas pesquisantes, tanto no ritual do fazer, quanto no ritual de escrever e apresentar os resíduos das investigações. Tais inquietudes geram e compõem - Livro de Artista com os resultados das conversas pesquisantes que se desaguam em poéticas visuais, de forma viva e, ao mesmo tempo, movediça, criando trilhas que me atravessaram na fluidez das viagens que me habitaram e afetaram enquanto performer andarilha entre Macapá e Belém.

A minha conexão com a expressão andarilha está engendrada com as sessenta viagens aérea e quatro fluviais, que realizei entre Amapá e Pará, no ano de 2016, quando vivenciava/estudava as disciplinas ofertadas pelo Programa de Mestrado. Nesse momento, andarilhava pela parte urbana das cidades de mototáxi, ônibus, a pé, Uber e carona dos colegas andarilhos da turma do Curso ProfArtes. Essas relações foram atravessando-me e alinhavando a pesquisa; não tinha como fugir, pois, as viagens teciam as conversas nos aeroportos com pessoas-livros-sites que visitava pelo celular, enquanto aguardava os voos. E nessa linha de pensamento, a autora Marques (2017) afirma que:

O pesquisador andarilho, que observa e ao mesmo tempo é parte daquela movimentação, se desloca e se infiltra na complexidade e heterogeneidade da cidade, vive os meandros e as estranhezas do cotidiano, que the é tão familiar e ao mesmo tempo exótico para sua percepção. Esta condição disposta pela noção de andarilho é o sentido de fazer pesquisa 
nos termos de uma etnografia da cidade (AGIER, 2011) que se faz pela experiência localizada, da descoberta e de (re)conhecimento, percebendo movimentações e situações ocorridas no espaço social da cidade como fonte de interações complexas e da diversidade (MARQUES, 2017, p. 38).

Envolvida nessas movimentações nas cidades como performer andarilha (entre)cruzava minha corporeidade com pontos de ônibus num correcorre de pessoas, fugindo da chuva da tarde ou dos assaltos nos (entre) meios das avenidas Nazaré e Magalhães Barata da cidade de Belém, vias que conduziam o meu corpo performático para o prédio do PPGARTES, ao parar para descansar nas bancas de revistas, conversava metaforicamente com Foucault, Galimbert, Didihuberman, Freud e Friedrich Nietzsche. Destas conversas, a/r/tografei as linhas de pensamento sobre corpo, educação, relações dos sujeitos com a sociedade, com as imagens através de uma nova filosofia que desenterra os sentidos e narrativas que estão submersos nas imagens e com os (in) tertícios, que (des)dobravam o meu olhar numa interação (con)tínua com os lugares, numa busca constante em (des)vendar a vida cotidiana por meio dos meus fazeres artísticos.

$E$ nesses entremeios andarilhos, entram no trajeto dos percursos pesquisante, o café-com ou sem leite-chocolate-capuccino, que foram cúmplices e companheiros durante as viagens por ar, terra, mar e nas casas que me acolheram nas cidades andarilhadas. Muitas vezes, acordavamme durante a sonolência da gestação marcando relações diretas e (inter)culturais com essa cansada corporeidade andarilha. Estas relações foram $A / r /$ tografadas no meu corpo, agendas, cadernos de anotações, celulares e, ao longo dos caminhos deram corpo as minhas metodologias durante as viagens que, também, as transformaram-se em espaços de investigação e (des)cobertas. E o meu corpo andarilho se fez presente neste processo. A imagem 01 é um registro:

As minhas viagens se transformaram em um estado de (des)locamentos (cons)tantes, havendo segundas e terças-feiras em que eu não sabia se estava acordando em Belém para ir ao PPGARTES, trocar conversas e buscar entranhamentosescritos-visuais e poéticos, ou em Macapá, preparando as minhas malas para ministrar aulas de teatro e artesanato no CCFA: a minha vida se

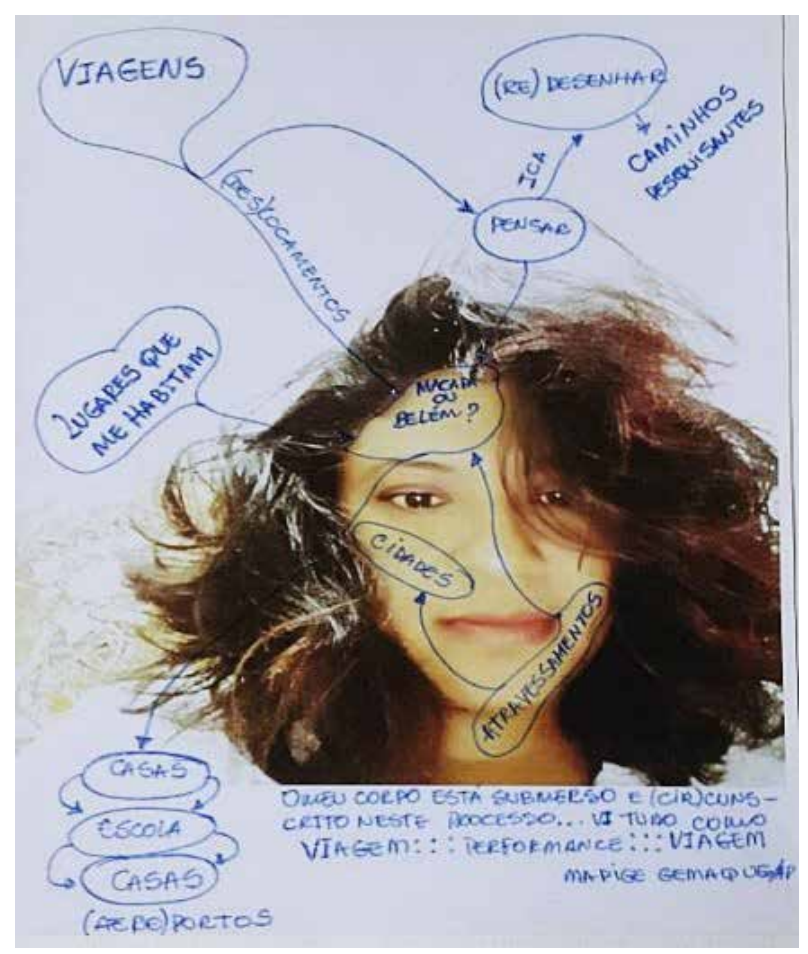

Figura 1 - Foto Performance, que re(de)senha os caminhos pesquisantes, 2017.

Fonte: Mapige ${ }^{5}$ Gemaque - acervo de pesquisa.

transformou num corre-corre, pra lá e pra cá, uma performer andarilha na região norte do Brasil.

As idas e vindas despertavam e provocavam o meu olhar de performer-professora-pesquisadora. Passei a viver, perceber, sentir e criar afetos com os lugares, acima das nuvens, tendo uma visão movediça e perigosa, já que as turbulências que atingiam a aeronave afetavam a minha corporeidade, minha cria, Rosa Sófia de Àurea Gemaque, pulava em meu corpo-casa-útero, e as contrações habitavam-nos (nos colocavam em contato).

Como numa performance viva, presente no meu corpo andarilho (des)construindo-se, e transformando-se num casulo, ao mesmo tempo em que gerou uma vida e, também, gestou um produto poético para o mestrado. A sensibilidade e a viagem para estes mundos (des)conhecidos afetavam-me, cotidianamente, tanto na pesquisa, quanto na gravidez, transferindo sensações, sintomas, dores, tenções, emoções e sonhos engendrados com a alquimia do universo $e$, por breves momentos, via-me como uma borboleta cheia de cores, vida e luz que deu vida à Sófia e a este livro de artista. Criando diálogos entre "a arte e a vida; para as vias de mão dupla entre ritual e 


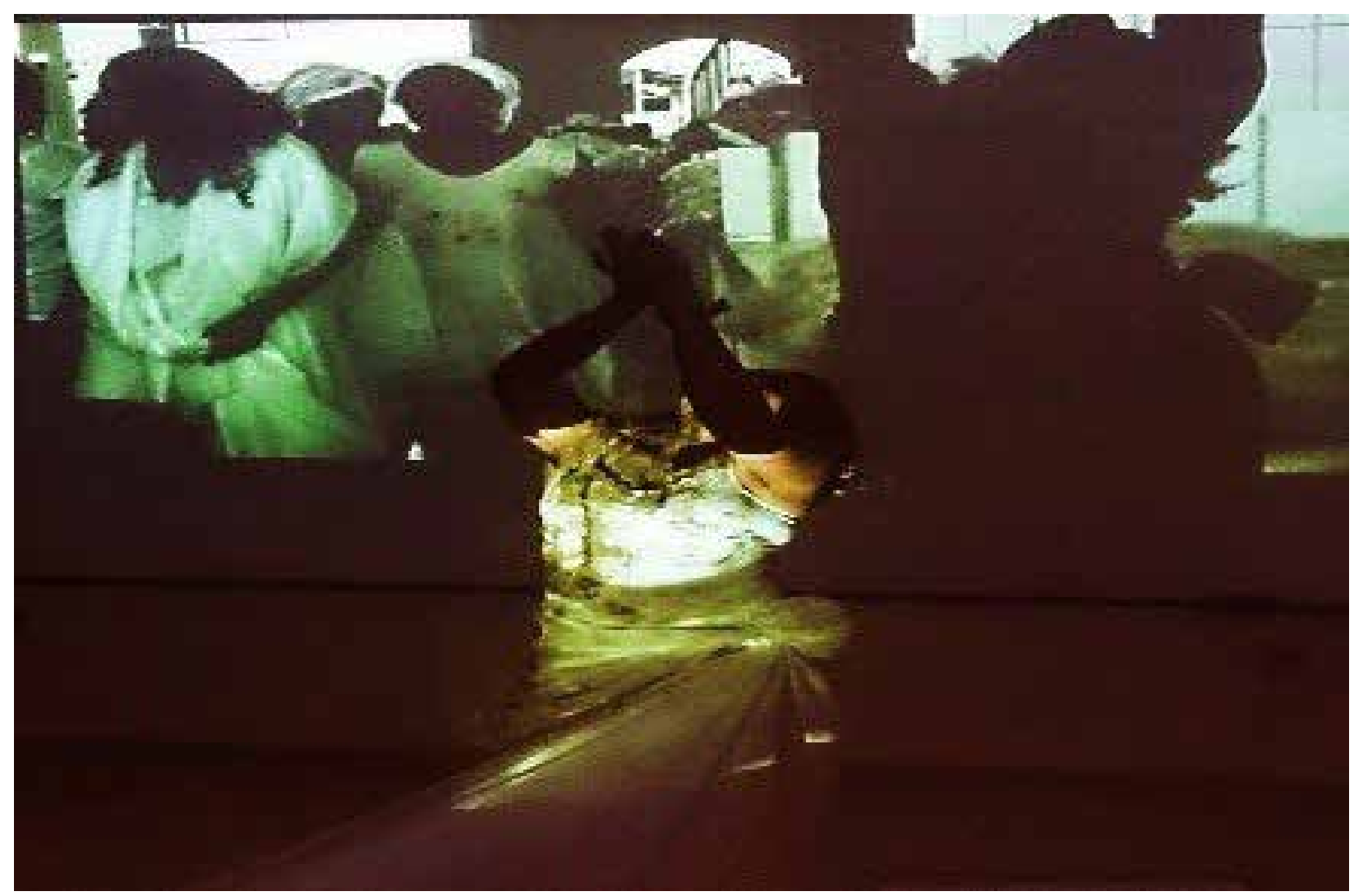

Figura 2 - Registro da performance estante do (in)visível - 02, criando interatividade com o vídeo registro da performance Estante do (in)visível - 01 (2014).

Fonte: Site da UNIFAP6.

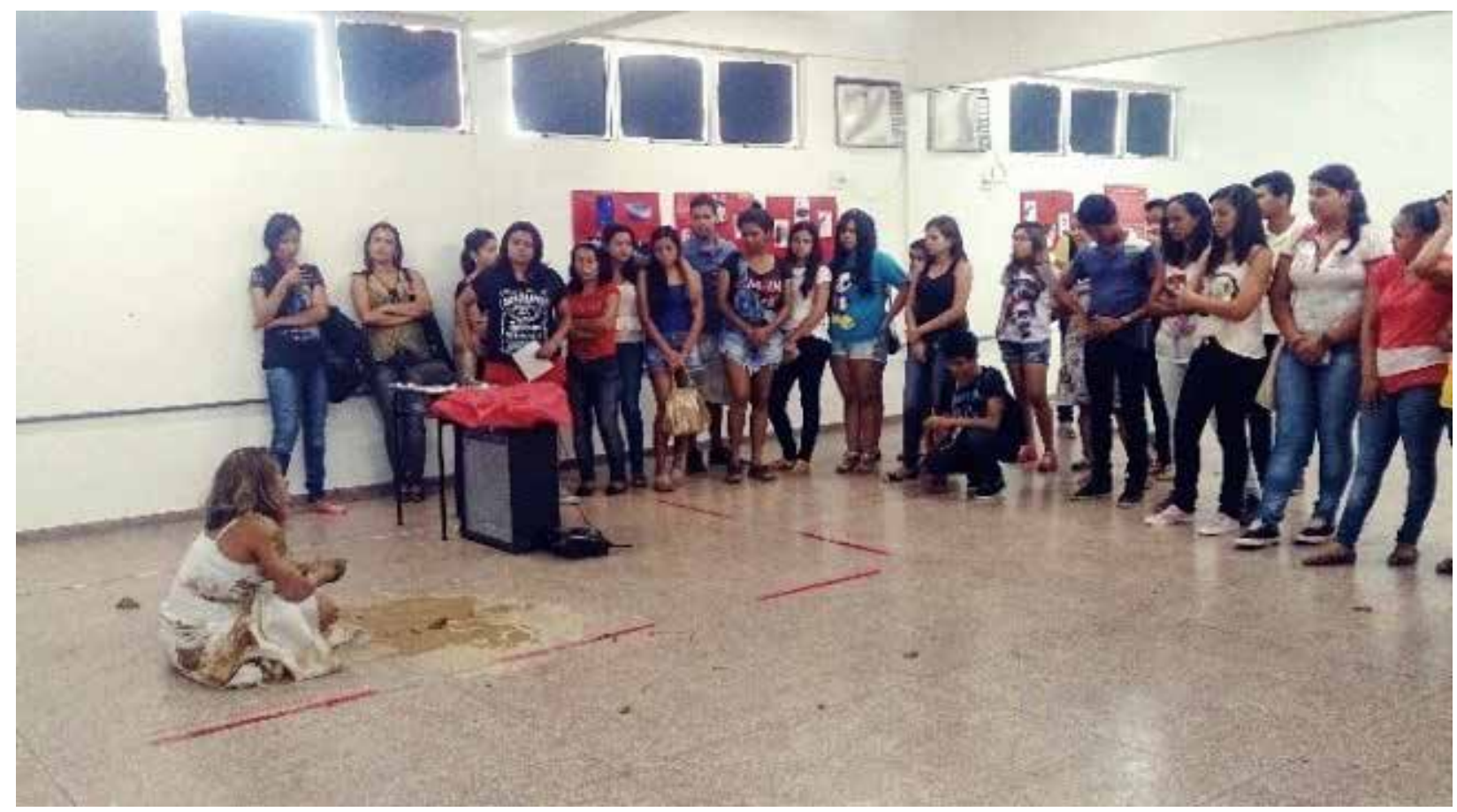

Figura 3 - MAPIGE faz uma conversa para criar interações e diálogos com estudantes do Ensino Médio, na galeria da UNIFAP (2014). Fonte: Site da UNIFAP? 
performance; para a importância da fugacidade do instante, da presença no aqui agora" (NUNES, 2016, p. 171). Neste momento performático, minha mente também começou a viajar, "criarpensar" (RANGEL, 2006, p. 02) vários caminhos de percepções sobre as duas cidades e os espaços que as formam ou as (de)formam.

Criando conexão com os atos e processos de criação de forma diferente-inovadora e subjetiva, pois tinha que "re(de)senhar" (RANGEL, 2006, p. 02) os rituais performáticos sensações, curiosidades, provocações, interações de pertencimento entre o meu corpo andarilho e os lugares. Percebi que o Rio Amazonas ligava as cidades e levavam-me para as tramas (in)visíveis que me transmitem leveza, energias e muitas viagens onde o meu corpo se faz presente, criando caminhos entre lugares/ espaços cheios e vazios e, em minhas buscas transformaram-se em sintomas e entranharam-se no meu fazer artístico.

Esse "sintoma representa a realização de dois desejos contrários" (DIDI-HUBERMAN, 2013, p. 263), que me impulsionaram a (des)cobrir/(des) vendar estes vazios que também estão cheios e, nas minhas buscas, desaguaram-se na realização do produto artístico. Os sintomas que me afetaram transbordaram e, na ânsia em busca de formas sobre os processos de criações, deram vida ao Livro de Artista que será desvelado no subitem a seguir.

\section{ENTRE CONVERSAS, VIAGENS E OLHARES: PROCESSO CRIATIVO DE UM LIVRO DE ARTISTA (IN)CORPO-AÇÃO}

O livro de artista foi produzido com a intenção de criar caminhos metodológicos para trabalhar com arte contemporânea e com processos de criação em performance e poéticas visuais no espaço escolar nas aulas de arte. Ainda hoje, tais fazeres representam um desafio para os artistasprofessores, por causar estranhamentos efêmeros ao dialogar diretamente com o cotidiano, tão limítrofe à própria vida do artista/professor/ pesquisador. $E$ nessa busca (cons)tante por caminhos metodológicos, percebi que a professora Rosilene Lobato criou um canal entre a performance e a escola, transformando a poética em uma forma de ensino, criando, a partir da performance, deslizamentos de criação. As imagens 02 e 03, são registros dessa interação:
Nessa conversa expressa nos textos visuais, a arte contemporânea parecia um monstro. Aliás, a performance! E a partir deste (entre)cruzamento, passei a pensar num dispositivo que pudesse contribuir com os processos de criações em performance e poética visuais. Como artistaprofessoras trabalhamos, metodologicamente, com rodas de conversas, num trocadilho, onde as formas de produzir o que somos, provém das interações contínuas com outros, na intenção de que, a partir destas conversas, os estudantes pudessem criar relações com a performance e com as poéticas visuais. Para a artista-professora Lucimar Bello (1995, p. 162), “o conversar (falar escutar) significa que a vida de uma pessoa está inserida na vida de outra pessoa, e os sentimentos próprios de uma outra e de outra são evocados pela linguagem verbal e pelas imagens." E é por isso que a professora Rosilene Lobato anuncia que:

\begin{abstract}
A ideia de levar professor artista para a escola surgiu a partir da necessidade de se trabalhar a arte contemporânea nas aulas de arte. Foi por isso, que convidei a Mapige, quando à encontrei em sua exposição denominada estante do (in)visível - 02, na Galeria da UNIFAP em 2014 e desde este período a artista é parceira do Projeto de Exposição Submersa. Já que a princípio, é um conteúdo desafiador para o aluno, pelo fato de não ser um conteúdo habitual na sua vivência estudantil, mas a partir do momento que ele conversa com os artistas convidados e faz pesquisas, fundamenta-se, e faz sua proposta de trabalho e, logo encontra uma nova referência em estudar arte contemporânea, por meio da performance, dos vídeos, das instalações, intervenções e desenhos. (LOBATO, 2017).
\end{abstract}

Envolvida por este desafio, gestei ${ }^{8}$ o Livro de Artista, a partir do momento em que senti a necessidade de ter um dispositivo para produzir os processos de criações com estudantes e articular encontros e cafés, guiados por conversas entre a o ensino da arte, a prática artística e a comunidade, durante a execução do projeto de criações poéticas com rituais performáticos na Escola. Já que a pesquisa engendra sujeitos da escola e do bairro nas minhas viagens, conversas, na criação artística e nos atravessamentos.

Passei a pensar e "Re(de)senhar" (RANGEL, 2006, p. 02), tudo que estava submerso na minha "casacorpo-mundo-cosmo" (RANGEL, 2006, p. 02), performático, já que a casa é o lugar que me abriga, fisicamente, emite-me segurança, proteção e guarda em seu corpo os registros escritos, visuais e audiovisuais dos fazeres artísticos que me habitam 


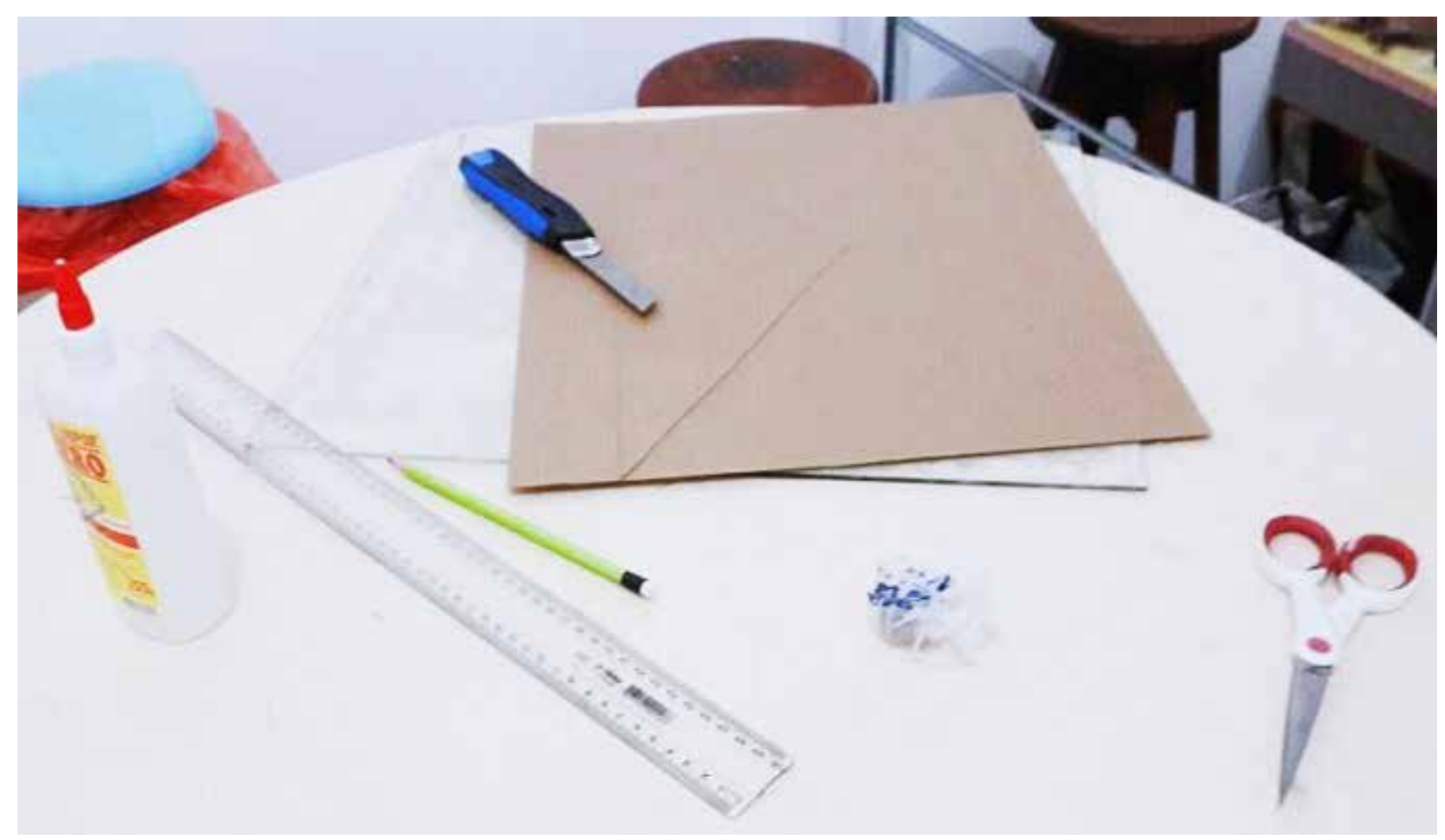

Figura 4 - Rede/processo de criação de um Livro de Artista. Fonte: Acervo de pesquisa - Mapige Gemaque (2017).

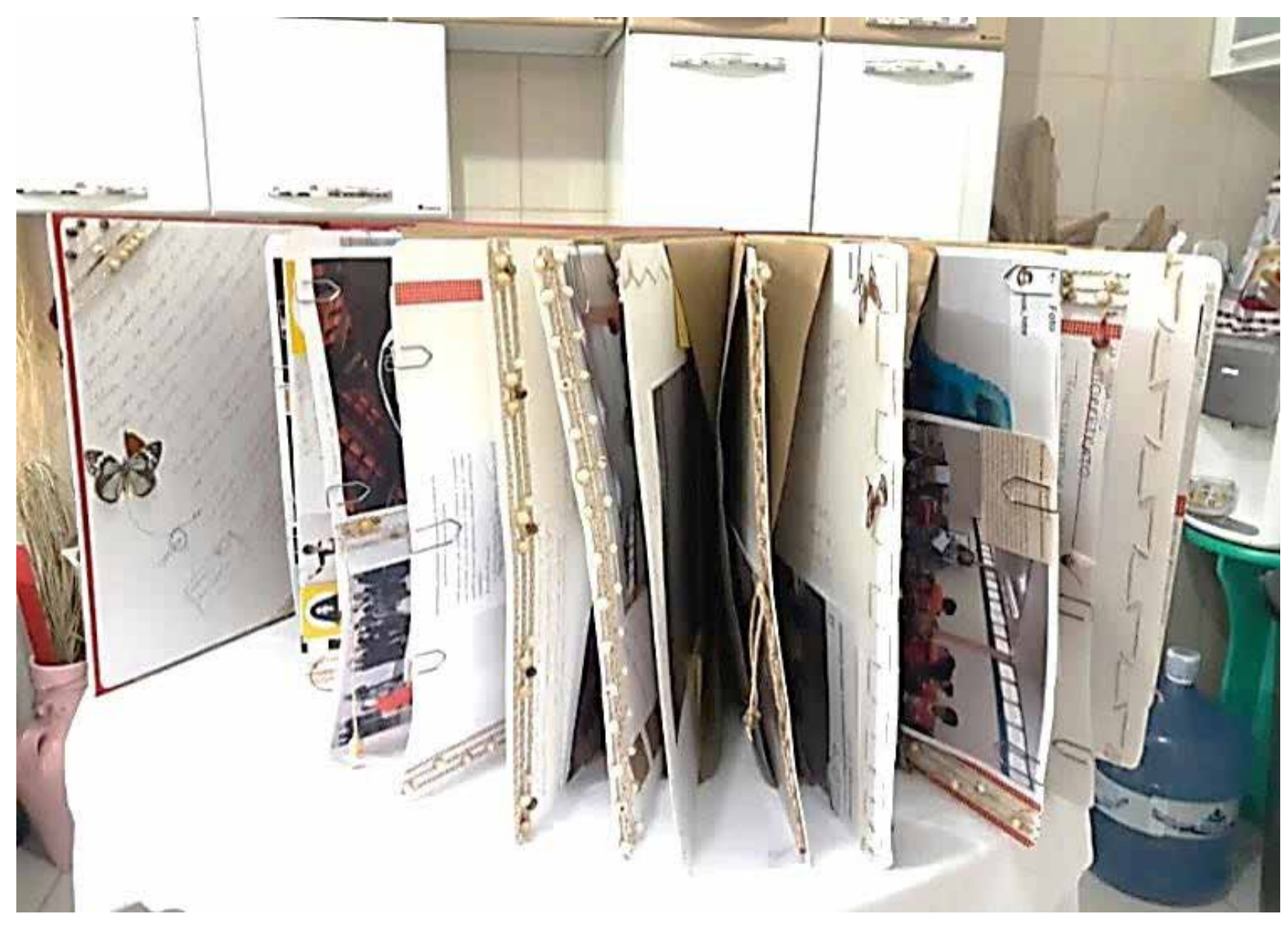

Figura 5 - Livro de Artista.

Fonte: Mapige Gemaque - acervo de pesquisa (2017). 
e, deste processo, nasceu um Livro de Artista, que "designa tanto a obra como a categoria artística" (SILVEIRA, 2008, p. 25), em constante (des) locamento "o qual, se constrói a partir da visão totalizadora do seu criador, fortemente ligada aos experimentos" (SILVEIRA, 2008, p. 33) do artista e pode ser industrial ou artesanal como este que foi produzido em forma de "rede da criação que poderá também ser da maior utilidade para professores e estudantes de escolas" (SALLES, 2014, p. 12), tal como foi nesta vivência que realizamos na escola, onde ocorreu a pesquisa. E a imagem 04 é um registro do processo de criação:

Essa imagem operatória faz conexão com o pensamento da autora Sandra Rey, ao afirmar que "uma ideia é uma representação da mente. É um objeto interior que se apoia e se constrói por meio de imagens difusas e oníricas. Uma ideia só existe quando expressa, senão permanece como uma elaboração mental e fugidia" (REY, 2008, p. 70). $E$ foi nessa linha de pensamento defendida pela autora que iniciei a produção do livro, até porque os estudantes precisavam de objetos artísticos reais, e que configurassem em seus corpos caminhos para tecerem as suas poéticas na escola campo. Os estudantes, os professores e as pessoas podem tirar as folhas do livro, colocar da forma que almejarem, e reorganizar de acordo com as suas buscas, podem excluir elementos e inserir outros se desejarem.

O livro de artista dá possibilidade de um ensino de arte performático, cria deslocamentos entre ciência, metodologia e que tem como base a a/r/tográfia, que me possibilitou (re)inventar as conversas entre o fazer e a teoria. A imagem - 05 registra da estrutura do livro-objeto/livro de artista.

Quando uma estudante me perguntou: como é este livro de artista? Nesse momento, olhei para o livro, em seguida peguei, coloquei sobre a mesa e abrir; ao abri-lo, instalei sobre a mesa e começamos a movê-lo para um lado e para o outro. Estávamos manuseando um "livro de artista que chega a ganhar o espaço se confundindo com uma escultura ou instalação, ele é, portanto, um híbrido entre palavra-imagem-objeto" (BASCHIROTTO, 2006, p. 111). Envolvida por esse sintoma híbrido mencionado pela autora, respondi à pergunta da estudante como artista, ou seja, fazendo "uma análise que se instaura a partir do ponto de vista da criação. O artista está sempre do lado do processo: na criação da obra e na escrita" (REY, 2008, p. 70).

E nesse "apontamento" (REY, 2008, p. 68), sinalizado pela autora, falei para a aluna que 0 livro era inacabado, estranho, desorganizado, diferente, nem pronto, nem acabado. Apesar de fragmentado, em nenhum momento pensei numa estrutura formal com início, meio e fim. É um objeto que tem um corpo performático movediço, para uns pode despertar (de)sestabilidade, para outros é uma forma de viagem artística e de ensino de arte contemporânea. Proporciona várias entradas, gavetas, portas e cria muitos (des)locamentos. Qualquer pessoa pode pegar e manusear como quiser, não tem uma orientação, até porque, não é um livro qualquer, é um Livro de Artista (!) que provoca sensações, experiências, sintomas, entre outras sensações. E seguiu um "processo de criação" em arte re(de)senhado em viagens, sintomas, mesas de café, momentos de conversas/ encontros com estudantes, professores, artistas, pesquisadores, críticos de arte e escritores que sustentam as minhas buscas. E tem mais, o livro não é só escrito! É imagético-simbólico-e-A/R/ tográfico. Ora está vazio, ora está cheio! As pessoas podem tirar e colar o seu corpo, é todo (des)locado e (des)colado. Como um sintoma que se "desloca: migra e se metamorfoseia" (DIDIHUBERMAN, 2013, p. 268).

Ainda nessa conversa, uma pessoa perguntoume como eu viajo nesse livro, ou como eu posso acessar o saber que você produziu neste objeto que não é meramente escrito. É pegando, optando, conversando, criando viagens e tendo outras sensações, referências, formas, hyperlinks que você pode criar sem legenda e o guia do livro será você, ou seja, o próprio leitor. Pois, "não há sensação isolada ou separada - é um estado que começa continuando o anterior e termina se perdendo nos posteriores. Uma imagem evoca, em cada uma das extremidades, uma outra imagem" (SALLES, 2014, p. 67). Aqui a autora promove encontros que, ao mesmo tempo em que são perceptivos, também se fazem criativos e que estão entranhados em nossa corporeidade em imagens que vagueiam pelas lembranças e memórias geradas na alma do ser artista e do espectador e que gestam outras viagens de criações poéticas. Desse (entre)cruzamento viajante entre memória, (des)loco o olhar para a capa do livro de artista, a imagem - 06 expressa as narrativas desse processo: 


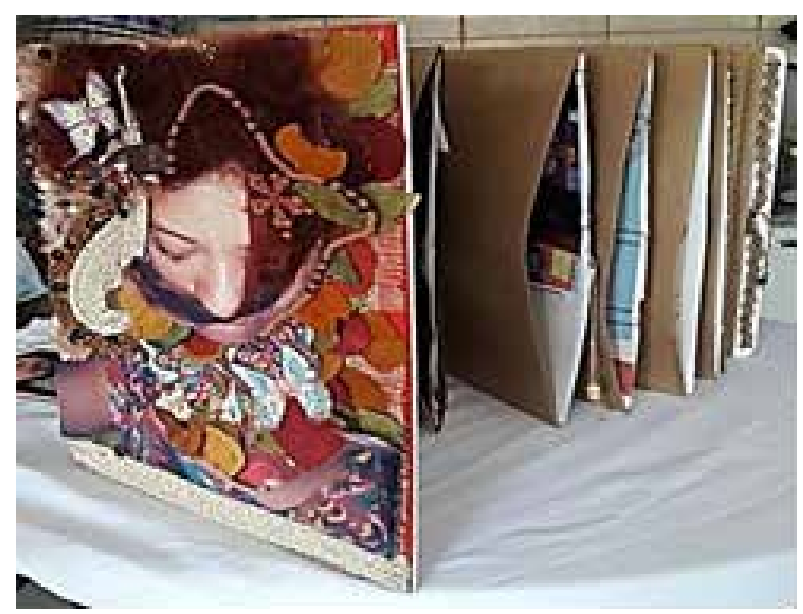

Figura 6 - Capa do Livro de Artista. Expressa os processos de criações artísticas e as relações com outros artistas.

Fonte: Mapige Gemaque - acervo da pesquisa (2017).

Aqui, estou submersa em tudo que me afetou! A capa vem das minhas viagens com a artista mexicana Frida Kahlo. Como artista, estou atravessada em tudo que me desloca das ribeiras amazônicas para o mundo. Assim como Frida Kahlo estava entranhada na cultura mexicana e transformou suas dores em cores para viver os seus caminhos artísticos e cotidianos, (des) construí as minhas dores para (re)construí-las neste objeto de arte, para que outras pessoas também possam criar suas viagens, e possam expressar o que desejarem através da poética, assim como Frida Kahlo deixou suas impressões em seu diário, que também, é considerado "livro de artista como um diário, em formato tradicional códex, que ainda imprime o gesto de folhear" (BASCHIROTTO, 2017, p. 108).

Tudo que aprendi nessas conversas, nesses olhares, transformei em imagens, rabiscos, anotações, lembretes, desenhos, croquis, sintomas, trocas, viagens e (des)locamentos! Já que, "a obra não é fruto de uma grande ideia localizada em momentos iniciais do processo, mas está espalhada pelo percurso. Há criações em diários, anotações e rascunhos" (SALLES, 2014, p. 37). Para a autora, a criação vem de uma grande rede que me obriga a lancear ${ }^{9}$ pelos quintais do meu corpo poético, para pescar os objetos necessários para a produção do livro de artista que carrega em suas folhas elementos para criações poéticas, com pessoas ditas não artistas, ou seja, estudantes da escola campo.
Nesta conversa, Salles (2014) mostrou-me que a criação poética não tem início, meio e fim, é um processo contínuo em constante (trans)formação, aberto, interativo e "inacabado"! Quando pensamos:

Em criação como processo, já implica movimento e continuidade: um tempo contínuo e permanente com rumos vagos. A criação é, sob esse ponto de vista, um projeto que está sempre em estado de construção, suprindo a necessidade e desejos do artista, sempre em renovação. O sentimento de que aquilo que se procura não é nunca plenamente alcançado leva a uma busca constante que se prolonga, que dura. 0 tempo da criação está estreitamente relacionado, portanto, ao tempo da configuração do projeto poético (SALLES, 2014, p. 59).

Em minhas buscas por estes rumos vagos, percebi que precisava falar para os estudantes sobre os caminhos que percorro para fazer uma performance, e como se dá este processo, já que o ensino de arte, muitas vezes, ainda se pauta em uma linearidade cronológica e temporal da história da arte. Era o momento de tirar esta "máscara" e criar outro (des)locamento poético. Mas, como faço o meu processo? A partir de buscas, viagens, conversas, cafés e encontros com lugares. Diante destes sintomas, comecei a pensar em objetos artísticos que pudessem proporcionar encontros e fazeres com estudantes de forma viva e interativa, para atender as necessidades dos estudantes, nas aulas da Professora Rosilene Lobato e com artistas convidados. Quatro conversas e o roteiro do Richard Schechner eram o norte, e o que ia acontecer a partir delas eu não sabia!

Ainda acorpada/embebecida pelas conversas, levamos para a escola uma forma de roteiro/ receita nem pronta, nem acabada, com base nas interações do teórico Richard Schechner (2006), em que onde o autor estrutura uma linha de criação para as experimentações performativas. No roteiro da pesquisa, pensando a escrita também como um ato performativo, busquei estruturar o projeto nesse pensamento: Leitura, Produção e Execução. Para viajar, pesquisar temas, lugares, materiais, formas de re(de)senhar as poéticas visuais e (cons) truir diálogos com os artistas.

\section{OS ENTRE MEIOS DAS CONVERSAS POÉTICAS NOS ENCONTROS NA ESCOLA}

Iniciamos os encontros com a apresentação do projeto, em seguida, exibimos os registros audiovisuais da quinta Mostra Nacional de Vídeos 
e Intervenções performáticos (IP), em 2017, no auditório da escola, através de uma gentileza artística com o Coletivo Camaradas do Crato-CE e Coletivo Psicodélico/AP, e aproveitamos esse momento para envolver os professores e estudantes do terceiro ano do Ensino Médio, pois a Professora Rosi Lobato conseguiu negociar com os docentes os dias e horários de aulas, para desenvolvermos os processos de criações poéticas, ou seja, cederam seu espaço para a vivência realizada pelo ensino de arte no laboratório. As professoras de história, geografia, matemática e língua portuguesa participaram das conversas e tomaram o processo como instrumento avaliativo e vivenciaram alguns momentos. Este (des)locamento vem costurar uma lacuna muito grande que nós temos nas artes visuais, essa imersão entre as áreas de conhecimentos nos proporcionou espaços e vivências, onde a Alessandra, professora de língua portuguesa percebeu que o:

Olhar mais atento do meu aluno, a questão da sensibilização. O trabalho com a sensibilidade, a interpretação sensitiva, muitas vezes esses alunos chegam pra gente de uma realidade muito dura, muito difícil, e a gente não para um momento para ouvi-los. Quais são essas angústias? Quais são essas coisas que as inquietam e a partir desse trabalho ver a movimentação deles em relação a essas inquietudes (ALESSANDRA, 2017).

Essas sensações e percepções criam caminhos e percursos entre as nossas conversas e vão atravessando alunos e professores. Na sequência, a artista convidada Emi Barbosa fez uma conversa sobre arte contemporânea, arte efêmera, performance, vídeo arte e intervenção com base nos estudos que desenvolve sobre as poéticas e no livro Arte em interação: Manual do Professor do Ensino Médio (2015), que os estudantes tinham acesso na escola, explorando os temas liberdade e agressividade, a partir da performance Rhythm 0 (Ritmo 0) da performer Marina Abramóvic, na qual a artista expõe uma mesa com vários objetos que poderiam agradar ou destruir com a intenção de construir diálogos com o público e falar sobre a performance. Ainda nesta conversa, falou sobre os vídeos da mostra (IP), para conceituar intervenção e instalação. Finalizando sua participação com a performance Música para meus ouvidos, em que a performer produz sons/ruídos com um garfo sobre um prato. A imagem 07 é um registro desta interação:

Após, a performance, os estudantes aproveitaram para fazer perguntas e tirar dúvidas sobre a

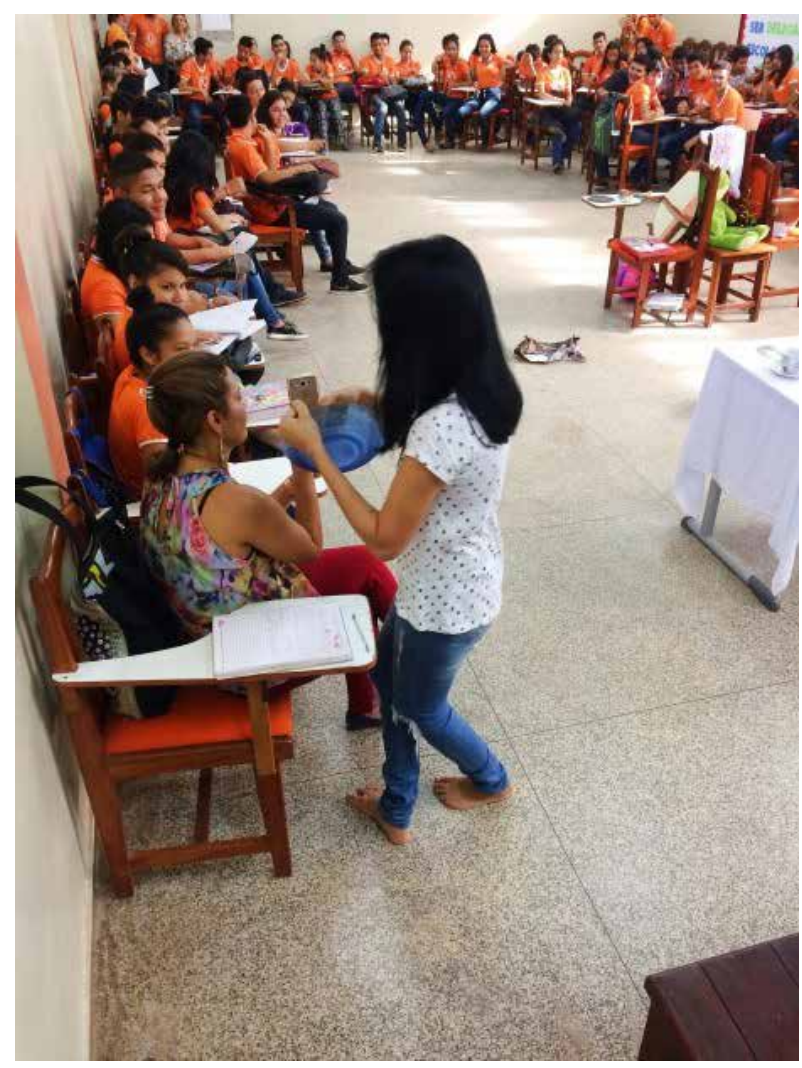

Figura 7 - Performance Música para meus ou(vi)dos, uma interação da performer Emi Barbosa com os estudantes. Fonte: Mapige Gemaque - acervo da pesquisa (2017).

poética apresentada, já que esta cena-poética não era comum no ambiente escolar, nas aulas de arte. É por isso, que a Professora-ArtistaPesquisadora Sandra Rey (2008) pondera que, "na arte contemporânea os limites entre arte e nãoarte são fluidos, sendo grande parte das propostas marcada pela ausência de fronteiras entre arte e vida" (REY, 2008, p. 68). E com a intenção de romper as fronteiras e aproximar os estudantes do cotidiano e da vida, tecemos os encontros com performance, registro de vídeo performance, instalação e intervenções, pois a "arte imiscui-se nas mais prosaicas esferas da vida cotidiana" (Idem, p. 68). E através dessa interação, os estudantes desdobraram olhares para as suas vivências com a realidade social, capturando elementos e fatos emblemáticos da sociedade, os quais desvelaram, em forma de poéticas, que foram apresentadas na ocupação da escola.

No segundo encontro, iniciamos os processos com a instalação de uma mesa de café, para criar vínculos, e romper as fronteiras que existiam entre nós. A 

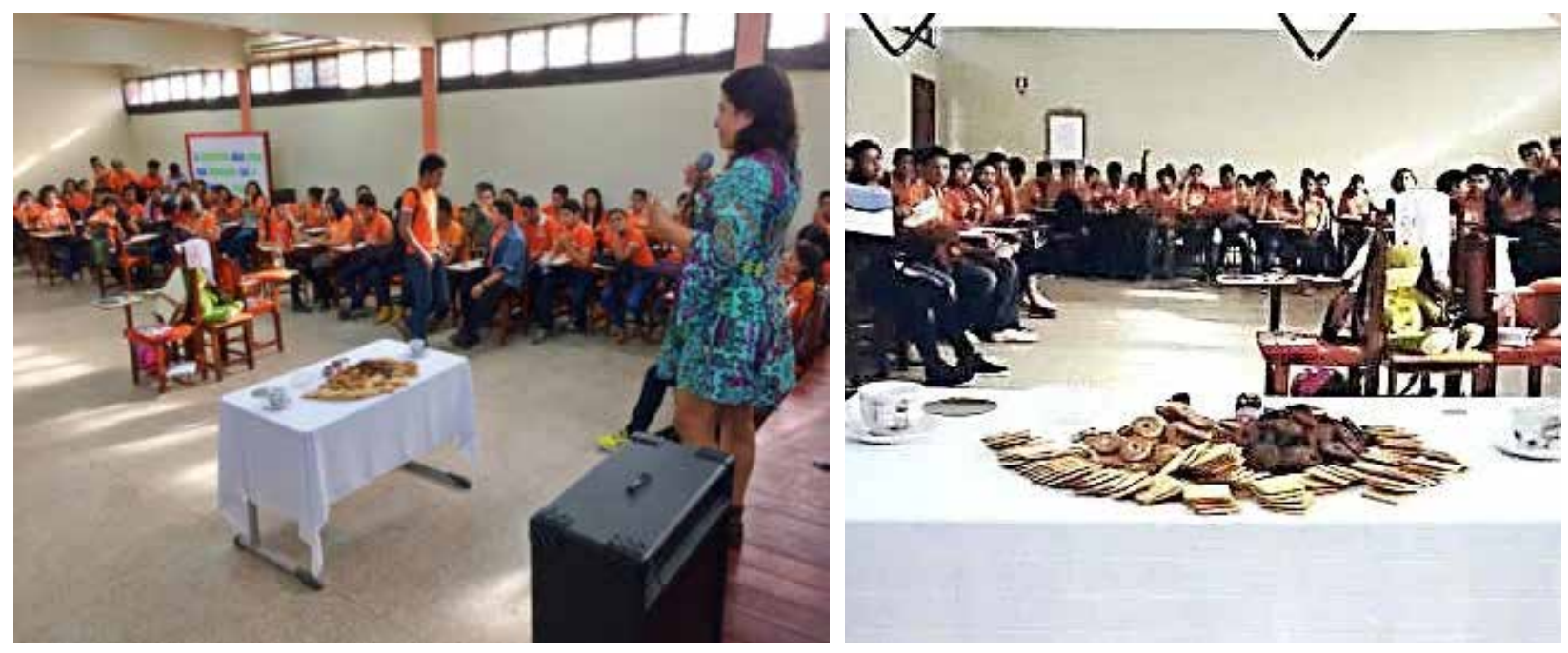

Figura 8 e 9 - Instalação: encontro, da artista MAPIGE, para criar conversas poéticas com estudantes.

Fonte: Mapige Gemaque - acervo de pesquisa (2017).

ideia seria diluir as fronteiras que a escola montou entre professores e alunos. Quanto às mesas, vêm das interações realizadas com mesas da performer Marina Abramóvic no primeiro encontro e com um workshop que participei em 2008, com a artista Selma Parreiras-GO que, naquele momento, fazia instalações em mesas com temas diversificados. Lembro de uma mesa que ela apresentou com joias, flores e lingerie.

A performance da Selma percorria pelas (dis) funcionalidades vivenciadas na vida a dois, nesta sociedade machista e preconceituosa, onde 0 homem fazia os seus devaneios e, para limpar a sua imagem com sua companheira, presenteava-a com os objetos que faziam parte da mesa da Selma naquele momento. Mas, nesses (entre)cruzamentos culturais, a artista ficou envolvida com a nossa cultura, e, também, montou uma mesa com cuias pretas de tacacá pintadas com açaí. Essas ações ficaram na minha memória imagética, ou como fala a autora Sônia Rangel (2006), "(a casa, o quintal e o jardim)" que guardam os meus processos poéticos. Pois, "os registros funcionam como uma memória sensível de possíveis bons encontros para a criação, cuja emoção é reativada nos atos de leitura e releitura [...]" (SALLES, 2014, p. 68).

Não parece uma releitura, é uma imagem que funcionou como elemento de "operação metodológica" (RANGEL, 2006, p. 01) e simbólica, para que criássemos uma interação entre a mesa de café que instalei no laboratório móvel da escola, com as mesas/formas de se tomar café nas casas dos estudantes. Foi uma forma de conhecê-los, a partir deles ou de elementos que temos em comum, para criar as nossas conversas e processos de criações. Parafraseando o teórico Michel Maffesoli (2014), tudo se partilha: comer, garimpar, descobrir, jogar conversa fora para (re)criar caminhos e formas de se fazer conversas poéticas. E a imagem 08 é um registro dessa ação-interativa entre memória cultura e arte:

Somos uma grande tribo, e ao nos imbricarmos com os outros, vamos hibridizando as nossas sensações e emoções. Das mesas de café, tecemos conversas com os estudantes, sobre os vídeos exibidos no primeiro encontro, e tomamos como elemento operatório para 0 ato de conversar, a imagem sentido? Capturada do vídeo performance do artista Joéser Alvares-RO, em que o artista pinta um quadro dentro do rio, com água do rio e depois pula no rio e mergulha seu corpo, deixando para os espectadores a imagem com a palavra sentido?

O texto visual apresenta a imagem do vídeo que afetou e atravessou os estudantes movendo-os a criarem uma imagem operatória no quadro do laboratório móvel da escola que:

operou articulando ação-imagem-sensaçãointuição, não necessariamente nesta ordem. Do ponto de vista da abordagem filosófica, inspirome no que defende Maffesoli em sua sociologia compreensiva, isto significa colocar-se dentro, em processo, em contato, sem pré-modelo a ser comprovado, sem um pré-conceito, numa atitude 


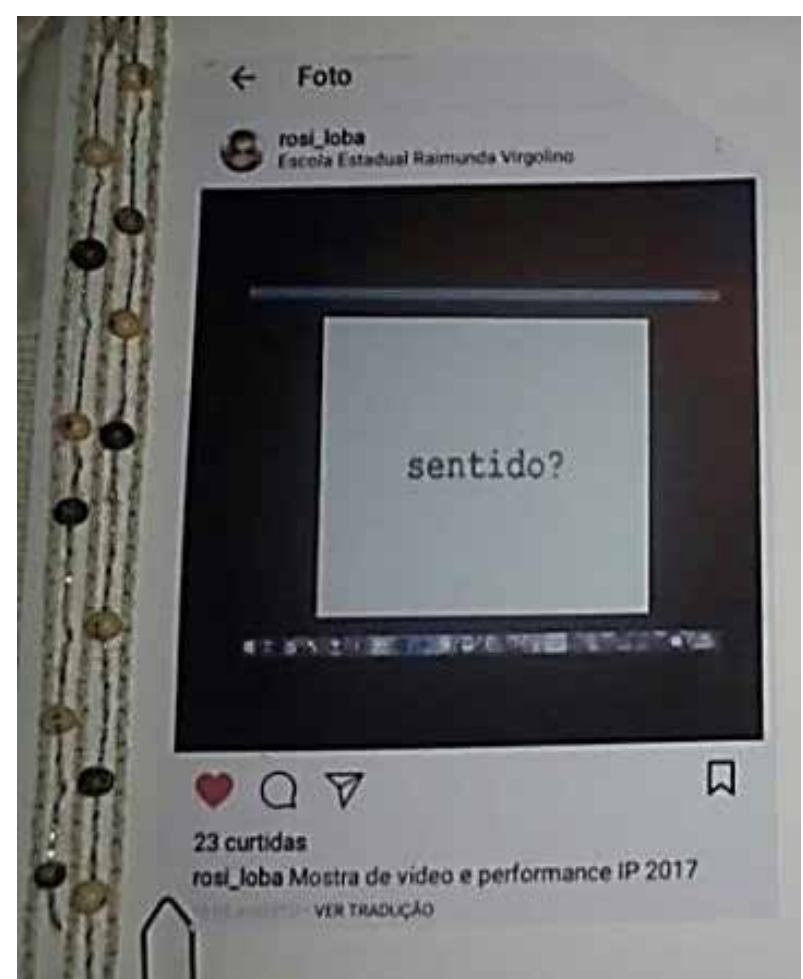

Figura 10 - registro da performance Sentido?

Do Performer Joéser Alvares-RO, 2017.

Fonte: Rosi Loba Instagram (2017).

de reconhecer o que emerge ou se configura como fluxos do pensamento encarnado nas ações, princípios da criação (RANGEL, 2006, p. 01).

Nessa conexão com a imagem operatória, mencionada pela autora, entre fluxos e processos de criações os estudantes imprimiram e expressaram os sintomas que ficaram entranhados em suas corporeidades, memórias, espaços de vivência e criação poética, através de um desenho com palavras que direcionaram a escolha da poética, que foi produzida por cada grupo que participou dos cafés e conversas artísticas no laboratório móvel, e a imagem - 10 é mais um registro.

Nesta fase da pesquisa, fui surpreendida pelos estudantes, não estava esperando esse desenho com palavras do ritual cotidiano da vida hibridizada, com palavras próprias da arte contemporânea. Tínhamos apenas uma imagem: sentidos? E a partir dela os estudantes criaram vários sintomas que vagueiam entre as nossas viagens e conversas pela arte, talvez, tenha sido por essa, (con)taminação poética que a estudante do terceiro ano do Ensino Médio, Maria Inês, fala que:

Essa forma de ensino, ela estimulou a interação dos alunos na sala de aula, e ela estimulou também a forma de aprendizado, por exemplo as instalações, elas mostram uma nova reflexão por vários ângulos da arte contemporânea e, isso com certeza influencia e mostra a importância da arte na sociedade para o indivíduo na sociedade (INÊS, 2017).

Logo, (des)loquei essa conversa para o Livro de Artista, pois a estudante falou que a arte contemporâneainterage, édiferente, desorganizada e mostra vários ângulos? "Pesquei" esses sintomas, desse processo de análises feito pelos estudantes. Até porque, "o sintoma se desloca: migra e se metamorfoseia" (DIDI-HUBERMAN, 2013, p. 267), e parece com o livro que apresenta vários sintomas e muitas viagens para construir poéticas visuais.

A partir do das experiências desenvolvidas no terceiro encontro na escola, convido para tecermos viagens poéticas, a partir das quatro conversas que estão no Livro de Artista. As conversas foram instaladas no meio da sala/laboratório móvel, junto com outros objetos que atuaram como "instrumento operatório" para que os alunos fizessem trânsitos com a sua memória, através de lembranças de pessoas, lugares-feridas-doresemoções-afetos-rodas-grupos, e cada grupo podia viajar e manusear o livro para escolher a conversa/ritual performático que desejava fazer a partir das orientações impressas no livro.

Nestas conversas, os estudantes tomaram como ponto de partida o olhar, e neste momento, uma estudante me falou, "nós conseguimos enxergar as coisas no outro, e para outro, mas em nós, não!" (Conversa de campo, 2017). Entranhei-me nesta conversa e falei para os alunos vamos (des)locar o nosso olhar para a nossa memória, o que você via na infância, e o que você não consegue mais ver no "aqui agora"? Já que, "para schechner, rituais são memórias coletivas codificadas em ações, ou seja, acrescento, em performances. A princípio, não faria sentido separar ritual, memória, arte e as contextualizações nas quais se expressam" (NUNES, 2016, p. 1250). E apartir da instigação os estudantes começaram a experimentar.

Viajaram nas tramas da infância interagindo com objetos que caminhavam entre os rituais das brincadeiras e dos objetos culturais, já que a "palavra poética tem que chegar ao grau de brinquedo para ser séria" (RANGEL, 2006, p. 02). E desse (entre)cruzamento trouxeram ainda os momentos da infância quando viviam com 


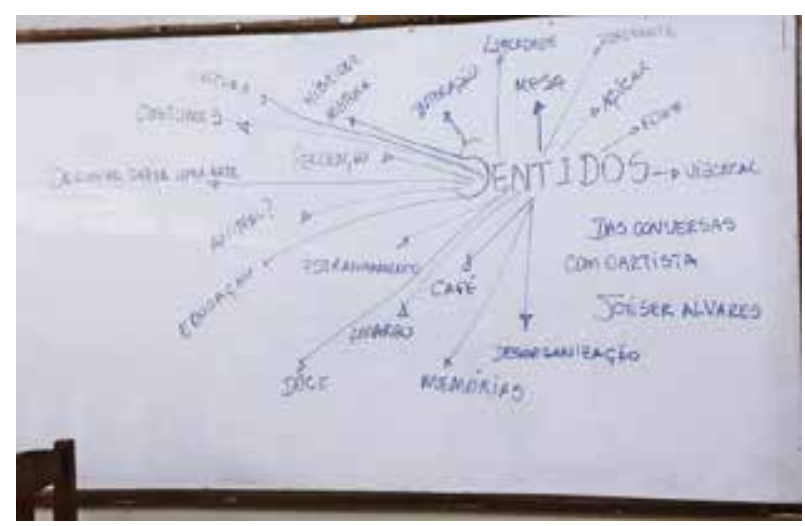

Figura 11 - registro da interação dos estudantes com o vídeo performance.

Fonte: Mapige Gemaque - Acervo de Pesquisa (2017).

seus avós nos quintais, ou terrenos plantando, regando, limpando e colhendo frutos. Falaram que não ligavam para o espelho quando crianças, porque a aparência não importava, mas agora ela (a aparência) faz com eles criem estes trânsitos e é uma forma de se conhecer.

O paneiro é um elemento típico das pessoas que moram nas ribeiras amazônica. Quando entrou em cena, os estudantes externaram saudadeslágrimas vítreas e emoções - quando uma estudante lembrou de seu pai que fora assassinado durante uma saída para pescar: "quando eu era criança, eu tinha o meu pai e agora não tenho, éramos felizes, tínhamos casa e agora não temos nem onde morar, a outra família dele tomou tudo que nós tínhamos" (conversas de campo, 2017). Além de trabalhar com as sensações, também criavam os autorretratos de suas realidades instigados pela conversa - 02 .

Outra aluna falou que não se olhava no espelho porque tinha uns quilos a mais e os seus colegas eram preconceituosos e a rechaçavam, mas agora essas questões já foram superadas. Houve um grupo que criou uma roda, onde cada um segurava um espelho para o outro se vê, a ideia foi falar de si através da imagem que viam no espelho do outro. As conversas além de criarem (des)locamentos artísticos, aproximaram os estudantes de suas vidas e realidades cotidianas.

Nestas conversas, crio (des)locamentos viajantes entre o vazio e os espaços das casas dos estudantes, através de diálogos com o autor Manuel de Barros. Estes vazios que fazem parte do livro e entram nas conversas foram sinalizados por um crítico de arte e, a partir deste interpelamento sobre os vazios que se entranham nos meus fazeres, busquei compreender e criar sentidos nas conversas, por meio dos espaços vazios. Será mesmo que são vazios? Após as conversas com os estudantes, eles falaram que nem tudo que está entre o vazio e o cheio configuram-se nestes conceitos. Houve grupos que falaram das suas emoções, sentimentos, amores e memórias contextualizando o vazio. Outros fizeram narrativas de espaços que expressam o vazio, tais como: os motéis que sinalizam o cheio, através das luzes vermelhas e o vazio pelas luzes verdes. Mas, eles sempre vão estar cheios de objetos, embora as luzes verdes estejam acionadas. E assim, teceram as conversas e deram forma aos seus processos poéticos articulando sentidos e caminhos de criações. Ainda nessa conexão, os estudantes criam interações com a conversa-04.

Deste atravessamento, passamos para a conversa de número quatro, que nos fala que a casa de uma pessoa diz mais sobre ela, do que ela mesma! Aqui, tanto eu, quanto os estudantes, passamos a deslocar os nossos olhares para os espaços das nossas casas, e nos encontramos em alguns. Da entrada da minha casa, desloquei para a escola a mesa, da cozinha, um fogão com botijão com gás, uma cafeteira e alimentos para instalar as mesas de "cafés (con)versantes" em nossos processos de criações na escola. Durante as conversas percebemos que as mesas e $\mathrm{o}$ ato de comer e conversar nos aproximavam. Nos encontramos também, através de objetos simbólicos que carregam as nossas lembranças, as nossas crenças. Dentre estes, mencionamos o filtro dos sonhos, as mandalas, as xícaras ou canecas de estimação, os bichos de pelúcia, os mobilhes, as fotografias e as formas de receber as pessoas com café, um ritual cotidiano que acontece diariamente nas ribeiras amazônicas, lembro como se fosse hoje, a minha avó servindo café para as visitas na ilha do Marajó, em Chaves/PA.

\section{OS RITUAIS/PROCESSOS CRIATIVOS PRODUZIDOS PELOS ESTUDANTES}

Nesse momento, os estudantes expressam, através das poéticas, as provocações-inquietudes e pesquisas que realizaram durante os encontros, conversas e cafés realizados na escola. Desvelando como resultado desses processos performance, intervenção, instalação e desenhos, na exposição Submersa ${ }^{10}$ em 29 de setembro de 2017. Passando a ser autores das obras que executaram. 


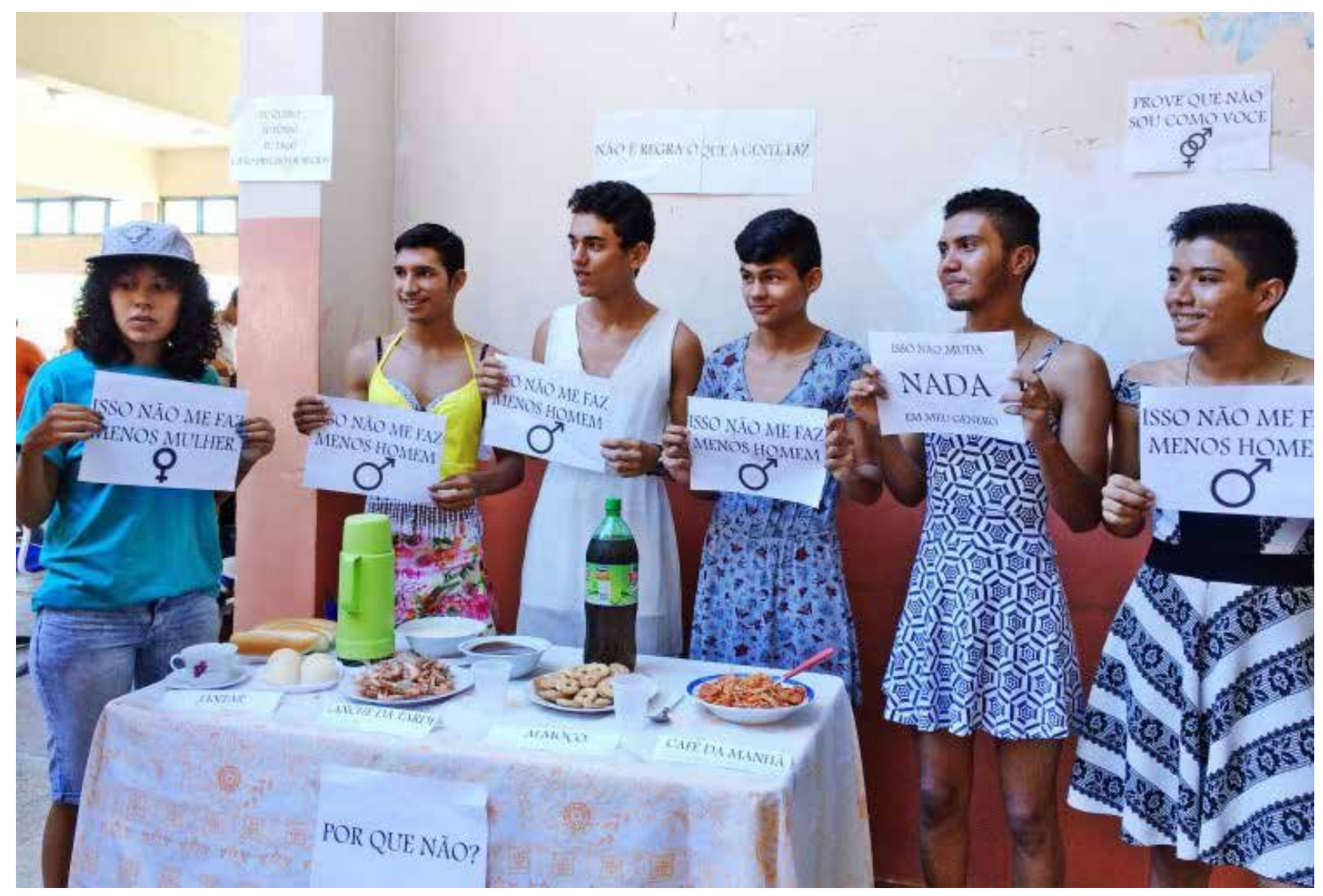

Figura 12 - Registro da performance: Quebra de Padrões. Fonte: Mapige Gemaque - acervo de pesquisa (2017).

Na imagem acima, os estudantes-autores trazem uma performance instalativa com o título: Quebra de padrões, que foi pensada durante os encontros com o livro grapefruit: de instruções e desenhos de Yoko Ono. Em nosso café, durante as conversas, fui interpelada por uma estudante deste grupo da seguinte forma: quem disse que quero tomar café de manhã, eu quero almoçar, e tomar café à tarde, vou fazer uma performance instalativa com este tema, os padrões me inquietam (conversa de campo, 2017). Já a imagem 12 traz uma mesa com a instalação: Ribeirinhos.

Essa instalação foi construída a partir dos (entre) cruzamentos dos estudantes com as ribeiras amazônicas e com os diálogos com as mesas da artista Selma Parreira-GO. Os trabalhos foram construídos a partir das relações dos estudantes com a sociedade, uma vez que estão inseridos nela e fazem parte de suas ações sociais e culturais. De acordo com NUNES (2016):

Performance é uma construção mental e física, na qual eu entro, frente a uma plateia, em tempo e lugar específicos. $\mathrm{E}$ ai que a performance realmente acontece; ela é baseada em valores de energia. É muito importante que o público esteja presente; eu não poderia fazê-la secretamente. Nem eu teria a energia para fazê-la. Para mim, é crucial que a energia venha realmente do produto e se traduza através de mim - eu a filtro e a deixo de ir de volta para a plateia. Quanto maior o público, melhor a performance, porque há mais energia com a qual eu posso trabalhar. Não se trata apenas de emoções. (...) você tem que estar no aqui e agora, cem por cento. Se você não está, o público é como um cão: ele sente a insegurança. Então, ele simplesmente o abandona (NUNES, 2016, p. 190-191).

De acordo com o autor, os trabalhos apresentados pelos estudantes, expressam os elementos da poética performática e dos temas/fatos que os inquietam nesta sociedade em que "o tribalismo é um fenômeno cultural" (MAFFESOLI, 2014), e os atravessam na contemporaneidade, uma vez que cada pessoa procura às 10 horas tomar café às 15 horas almoçar", e assim o fez através da sua tribo e cria as suas formas de vivências nos lugares. Talvez, tenha sido por isso que a estudante retrucou na conversa de campo que "preferia almoçar às 10 horas e tomar café às 15 horas", em sua performance.

Outro trabalho com tema pertinente-efêmero e visceral, escolhido pelos estudantes-autores foi à 


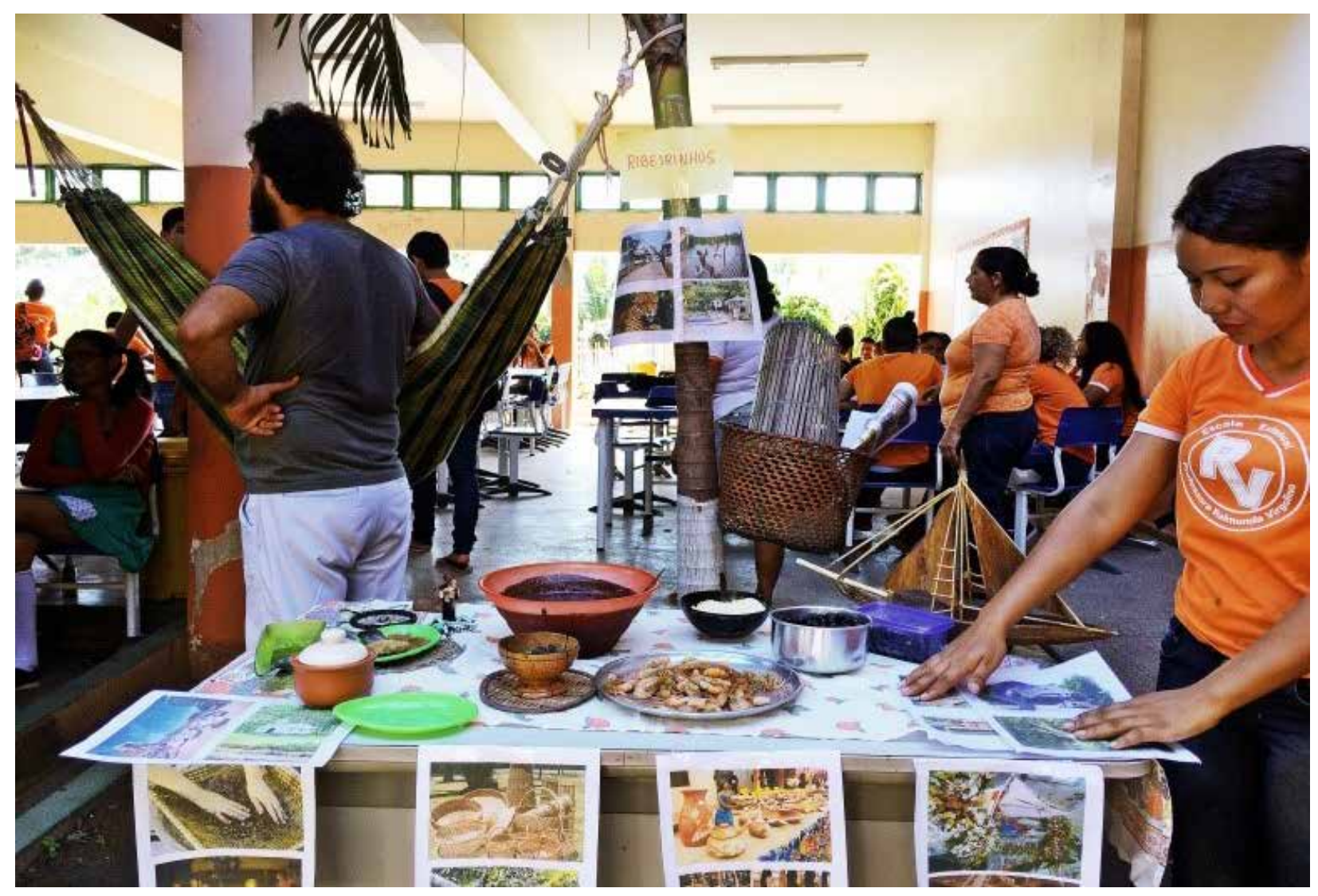

Figura 13 - Instalação: Ribeirinhos.

Fonte: Mapige Gemaque - acervo de pesquisa (2017).

instalação: denuncie! Abuso infantil é crime e pode está perto de você. Os alunos instalaram os objetos no corredor da escola sobre abuso-violência infantil com imagens fotográficas contendo textos de alerta, bonecos, bonecas, ursos e sapatinhos de bebê cobertos com sangue de esmalte vermelho, e algumas fitas atando as mãos, as bocas e os olhos, ações que expressam a submissão, pois a maioria destes casos acontece dentro de nossas casas. Quando vi esta obra, o meu corpo perdeu a mobilidade e senti uma dor (atra)vessando o meu corpo performático, e logo sai correndo atrás de minha cria. 0 trabalho era efêmero, visceral e cruel. A imagem 13 é um registro da instalação.

A instalação apresentou a simbologia do abusoviolência-infantil. $O$ objeto ficou exposto no corredor da escola, dando à composição múltiplas possibilidades metafóricas de viagens e interações. Logo, desloquei-me em direção ao grupo e perguntei, porque haviam trabalhado com o tema em questão e, uma estudante falou: "é algo que me inquieta, acompanho as matérias jornalísticas ${ }^{11}$ da cidade e só neste ano de 2017, quase 400 crianças foram abusadas, isso é um caos social, os responsáveis devem pagar por este crime, professora." Ao visitar o site, tomei conhecimento desse mal que circula em torno da infância de uma criança e, deixa sintomas que perduram por um bom tempo na vida das vítimas. Ainda bem que arte problematiza esta questão, enfrenta e denúncia.

Ainda nesse ritual, os estudantes-autores, realizaram muitos trabalhos, dentre eles performances sobre inquietudes, incertezas e dúvidas acerca da morte, em que fazem uma relação direta com os estranhamentos da arte contemporânea; performance: TV R.V, onde os estudantes-autores falam dos trânsitos e tramas dos mundos da televisão, como ela se encorpa nas pessoas e as influenciam; performance: quem sou eu? Que abordava questões sobre a crise existencial e a depressão, algo forte e pertinente nessa sociedade que excluí, discrimina e anula; performance: meus heróis morreram de overdose ou foram assinados! Os estudantes levantavam questionamentos sobre a simbologia da vida cotidiana interligada com a vida de artista famoso e com as químicas; performance instalativa: silêncio, aqui, um estudante com especialidade audiovisual 


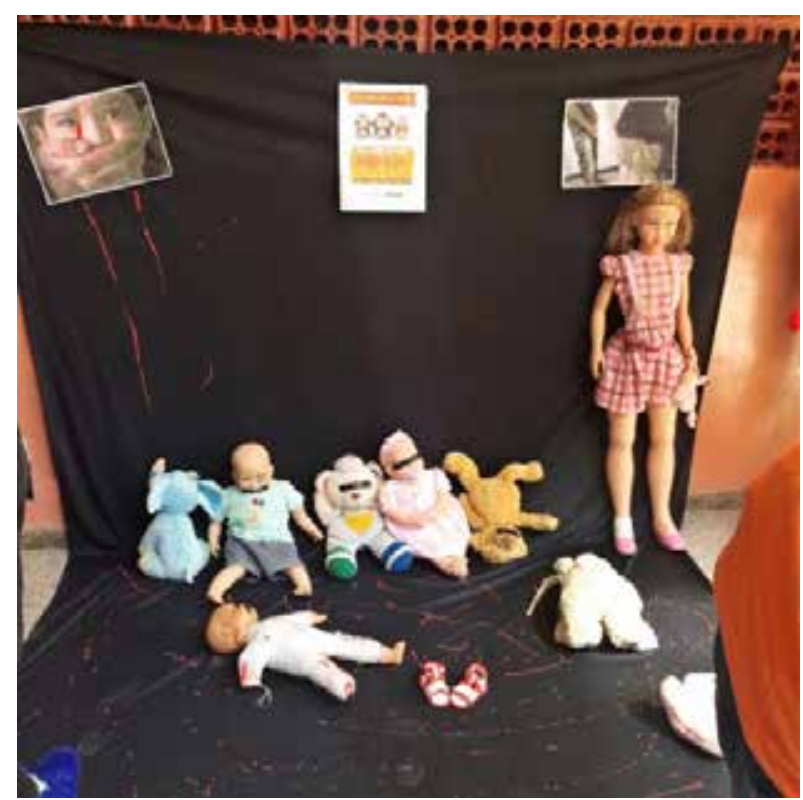

Figura 14 - Instalação denuncie.

Fonte: Mapige Gemaque - acervo de pesquisa (2017).

expressa a sua necessidade de incluir-se e comunicar-se com seus colegas. Para mais, foram realizados em torno de vinte e cinco trabalhos poéticos e em minhas análises, foram trabalhos de artistas, feito por estudantes para o corpo do ensino de arte, e para visitá-los, os interessados terão que acessar Livro de Artista que funcionou como dispositivo para as criações, enquanto processo pesquisante. Infelizmente, não temos espaço para falarmos de todos os trabalhos, mas foram magníficos.

\section{CONSIDERAÇÕES FINAIS: OS FINS-E-AFINS "INACABADOS" DAS CONVERSAS POÉTICAS}

Este artigo, fruto da pesquisa de mestrado em artes, buscou criar espaços de processos de criações poéticas dentro da escola através de conversas, cafés, viagens, deslocamentos, atravessamentos para compreender e fazer performance, instalação artística, intervenção e desenho no (Entre)cruzamento do ensino de arte. Sem dúvida, foi um desafio trabalhar com arte contemporânea nas aulas de Arte e ter como resultado a ocupação $A / R /$ tográfica da visualidade da escola, através da poética produzida pelos estudantes-autores de suas próprias obras. Mesmo diante das provocações, dos estranhamentos e das complexidades da experiência e das viagens, foi possível trazer para o público escolar a vivência poética presente nas narrativas/imagéticas/poéticas produzidas pelos alunos - autores conectados durante a vivência artística nas interfaces da escola, imprimindo nos trabalhos desenvolvidos suas marcas identitárias sobre corpo/memória/poética/ cidade/escola e atravessamentos.

Não conseguindo criar um espaço fixo, realizamos as experiências num espaço móvel, transitório, deslocado e cheio de sintomas para criar outras conversas. A professora de Arte Rosi Lobato negociou espaço e tempo com a escola e com seus colegas para ganharmos tempo. Alguns professores se envolveram nas ações e ficaram embebecidos pelos (des)locamentos que a arte contemporânea pode fazer no espaço da escola. Afinal, a arte contemporânea fala da vida e, durante o trabalho, foi possível criar estes trânsitos entre arte, memória, processos e lugares. De fato, esta vivência afetou a escola! E como produto destas interações temos um livro de artista com conversas para professores e pessoas interessadas em "viajar", um filme com a narrativa do processo, um roteiro com caminhos de criações e os registros das nossas vivências poéticas.

A ideia de viagem surge das minhas viagens como performer andarilha, já que é preciso viajar para (des)cobrir e, para ir além do que se busca, e do ser andarilho a partir do contato com a autora Silvia Marques (2017), ao descrever-se como pesquisadora andarilha. Espero que os processos aqui experimentados possam contribuir com artistas-professores-pesquisadores, tanto nos processos de criações artísticas, quanto nos espaços do ensino de arte. E finalmente, o trabalho está aberto a novas (con)tinuidades! Quem desejar, pode utilizar os materiais como processo de criações em poéticas no espaço do ensino de artes visuais.

\section{NOTAS}

1. Faço isso nos meus textos quando uso expressões/ palavras poéticas referentes aos processos de criações em arte, separando-as com hífen, barra e parênteses baseada nas propostas de Rangel (2006) e na pesquisa $A / r /$ tografica que permite essa licença poética ao professor artista que constrói sentidos sobre a sua prática no espaço da escola.

2. Expressão linguística usada no Amapá para referirse aos habitantes ribeirinhos da floresta amazônica.

3. Arte/educadora, atuante na Escola Estadual Raimunda Virgolino. Vale ressalvar que, tanto a 
professora, quanto as demais pessoas envolvidas neste trabalho autorizaram as suas identificações pela utilização de seus nomes e sobrenomes.

4. Do encontro com a performer MAPIGE, surge um convite e um deslizamento poético da galeria para a escola, tinha como objeto/dispositivo de criação com os estudantes a minha poética, que saiu dessa galeria e atravessou o muro da Escola Estadual Raimunda Virgolino no Bairro das Pedrinhas na cidade de Macapá, como material didático nas aulas da arte/educadora Rosilene Lobato. Lembrando uma arte fora da galeria, de Bia Medeiros do Coletivo Corpos Informáticos (2009), que me proporcionou a realizar um projeto de conversas poéticas, em artes visuais, envolvendo arte e política, performance e ritual, uma vez que utilizei como dispositivo a performance na escola, tendo como dimensão os atravessamentos entre a escola e as cidades, através da criação de um espaço de vivência poética móvel que estruturamos com a Rosilene Lobato no laboratório da escola e nas salas de aula. Mas, durante os primeiros encontros (con) versantes com estudantes, percebi que os mesmos foram afetados como espectadores e criaram sensações, impressões e conceitos durante as ações performáticas que foram propostas. Expressavam medo, estranhamentos, gritos, risos e correrias.

5. (MAPIGE) são as sílabas do meu nome e sobrenome que formam o meu nome artístico.

6. Disponívelem:http://www.unifap.br/estudantesde-escola-publica-visitam-exposicao-da-galeriade-artes-da-unifap/. Acesso em: set. 2017.

7. Idem.

8. Um trocadilho entre a gravidez e o processo de criação artística.

9. Uma forma de pescar com redes, nas ribeiras amazônicas (pesquisa de campo/vivenciada na ilha do Marajó-PA).

10. É o nome de um projeto de exposição de arte contemporânea realizado pela professora Rosi Lobato na escola campo. E foi pensando para criar este atravessamento entre artista-professor e os estudantes no ato de conhecer, fazer e vivenciar arte contemporânea.

11. Em 2017, um total de 398 crianças sofrem abuso sexual no Amapá. Esse dado é apenas o registrado nos atendimentos feitos pela polícia Técnico-Científica (Politec), segundo a qual a maior parte das vítimas são meninas entre 7 e 11 anos de idade. 0 número fica ainda mais alarmante quando se expõe o principal lugar onde os crimes acontecem, que é dentro da própria casa das vítimas. Disponível em: https://g1.globo.com/ap/ amapa/noticia/quase-400-casos-de-abusosexual-infantil-foram-registrados-no-amapaem-2017.ghtml. Acesso em: jan. 2018.

\section{REFERÊNCIAS}

AZAMBUJA, Diego; MARTINS, Fernando Aquino; MEDEIROS, Maria Beatriz de. CoRPOS INFORMÁticos. Arte, Cidade, Composição. 2006-2009. Brasília: Ed. Pós-graduação em arte da Universidade de Brasília, 2009.

BASCHIROTTO, Viviane. Livro de artista: palavraimagem-objeto. Revista-Valise, Porto Alegre, v. 6, n. 11, ano 6, julho de 2016, p. $101-112$.

DIDI-HUBERMAN, Georges. A imagem sobrevivente: história da arte e tempo dos fantasmas segundo Aby Warburg. Tradução de Vera Ribeiro, Rio de Janeiro: Contraponto; Museu de Arte do Rio, 2013.

BEUYS, Joseph. A revolução somos nós. In: COTRIM, Cecilia; FERREIRA, Glória (Org). Escritos de Artisitas: anos 60/70. Rio de Janeiro. Jorge Zahar, 2006.

DIAS, Belidson. A/r/tografia como metodologia e pedagogia em artes: uma introdução. In: DIAS, Belidson; IRWIN, Rita (Org.) Pesquisa Educacional

Baseada em Arte: $a / r /$ tografia. Santa Maria: Edufsm, 2013, p. 6-12.

FERNÁNDEZ, Tatiana e DIAS, Belidson. Pedagogias Culturais nas entre viradas: eventos visuais \& Artístico (Org.). MARTINS, Raimundo e a Pr. Irene. Pedagogias

Culturais. Santa Maria: Edufsm, 2014, p.101-137.

FREIRE, Paulo. Pedagogia da Autonomia: Saberes Necessários a prática educativa. São Paulo: Editora Paz e Terra, 2000.

IRWIN, Rita L. "A/r/tografia: uma introdução". In: DIAS, Belidson; IRWIN, Rita (Org.) Pesquisa

Educacional Baseada em Arte: $a / r /$ tografia. Santa Maria: Edufsm, 2013, p. 13-23. 
MAFFESOLI, Michel. 0 tempo das Tribos: 0 declínio do individualismo nas sociedades de massa. Tradução Maria de Lourdes Menezes; apresentação e revisão técnica Luiz Felipe Baêta Neves. 5 ed. Rio de Janeiro: Forense, 2014.

MARQUES, Silvia. Cidade Atelier: Poéticas e ações Artísticas na Amazônia. Coleção Gapuia - Sociologia em Pesquisas \& Teses. Ed. da Universidade Federal do Amapá, 2017.

MELIN, Regina. Performance nas artes visuais. Rio de Janeiro. Jorge Zahar Ed., 2008.

NICHOLS, Bill. Introdução ao Documentário. São Paulo: Papirus, 2005.

NUNES, Roberson. Haikay e Performance: Imagens Poéticas. Belo Horizonte: Editora UFMG, 2016.

SCHECHNER, Richard. "O que é performance?" In: Performance studies: na introduccion, second edition. New York \& London: Routledge, 2006, p. 2851. Disponível em: http://www.performancesculturais. emac.ufg.br/up/378/o/O_QUE_EH_PERF_ SCHECHNER.pdf. Acesso em: nov. 2017.

OLIVEIRA, Cassandra. Oficina: Introdução ao Documentário. Apostila da oficina realizada no $1^{\circ}$ Seminário de Audiovisual. Amapá, 2011.

SAlLES, Cecilia Almeida. Redes de Criação: Construção da obra de arte. $2^{a}$ ed. Horizone: Ed. São Paulo, 2006.

REY, Sandra. 10 Apontamentos sobre Arte Contemporânea e Pesquisa. Revista do Programa de Pós-Graduação em Arte, v. 7, n1, 2008. Brasília: Editora PPG - Arte UnB, 2008.

SILVEIRA, Paulo. A página violada: da ternura à injúria na construção do livro de artista, 2.ed. Porto Alegre: Editora da UFRGS, 2008. Disponível em: https://static.scielo.org/scielobooks/2pwn4/pdf/ silveira-9788538603900.pdf. Acessado em: set. 2017.

\section{DEPOIMENTOS}

LOBATO, Rosilene. Depoimento. Depoimento concedida a Mapige Gemaque. Macapá/AP, 2017.

INÊS, Maria. Depoimento. Depoimento concedida a Mapige Gemaque. Macapá/AP, 2017.

ALESSANDRA. Depoimento. Depoimento concedida a Mapige Gemaque. Macapá/AP, 2017.

\section{SOBRE A AUTORA}

Mestra em Artes pela UFPA; especialista em Artes Visuais Cultura e Criação pelo SENAC-AP; licenciada em Artes Visuais pela UNIFAP. É Professor(a)rtista na empresa GEA/AP lotada no Centro Cultural Franco Amapaense e desenvolve pesquisas e experimentos po(é)ticos em performance e arte contemporânea na Amazônia, através do Coletivo Psicodélico/AP. E-mail: mapigemapige@gmail.com 